\title{
Value foundations of marginal political practices of youth
}

\author{
Olesya Blinova $^{1, *}$, and Yuliya Gorbunova ${ }^{2}$ \\ ${ }^{1} \mathrm{PhD}$, Ural State pedagogical university, pr. Kosmonavtov, 26, 620017 Ekaterinburg, Russia \\ ${ }^{2} \mathrm{PhD}$, Moscow Witte University, second Kozhukhovsky p, 12/1, 115432 Moscow, Russia
}

\begin{abstract}
Today's youth, being a keyactor in the use of digital technologies, prefers digital participation in the political sphere of society. The main practices used by young people in their online participation are marginal. The marginality of the political practices of youth is revealed in their hybridity, which manifests itself in the binary of normativity abnormality, norm - deviation, etc. Using the trend-watching method in the course of the research made it possible to identify the nonlinear and virulent nature of the marginal practices of youth, which makes it difficult to predict their impact, that, according to the authors, actualizes the need to identify the value foundations of their application. Content analysis of young people (18-30 years old) accounts in social networks, Instagram and Youtube channels of public opinion leaders revealed such value foundations of marginal political practices of young people as: patriotism, solidarity, non-violence, participation and independence.The nature of the identified axiological foundations made it possible to draw a conclusion about the transition from the traditional values of political participation of young people to the values of self-expression, the acquisition and implementation of civic subjectivity.
\end{abstract}

\section{Introduction}

The development of digital technologies allows the political sphere to become more accessible and democratic. This fact erases the social and age restrictions on the possibility of participation and "entry" into it. Young people, being the most active social-age group, show an increased interest in political communication in the digital space. At the same time, Russian youth is ready (and often does not see an alternative) to use mostly marginal political practices.

By the marginal political practices of youth, we mean a form of non-institutionalized interaction that arises in the digital space and is implimented in reality, the result of which is the reproduction and transfiguration of social-political relations by young people, the acquisition of civic identity and the realization of civic subjectivity.

In the era of post-normality and post-marginality, post-politics, post-ideology and postdemocracy (S. Zizek, K. Crouch [1], J. Rancière [2], Z. Sardar, J. Urry [3], J. Ellul, S. P.

\footnotetext{
*Corresponding author: olesyablinova79@yandex.ru
} 
Bankovskaya , A. M. Vafin [4], E. V. Golovatsky [5], S. P. Gurin [6], N. V. Ivanova, Yu. A. Razinov, S. S. Horuzhy, L. L. Shpak [7] and others) the traditional binary oppositions for the discourse of marginality such as "moderation - extreme", "norm - deviation", "friend - alien", "minority - majority", "center - periphery" (G. Simmel [8], A. Schutz, R. Park [9], E. W. Stonequist [10], T. Parsons), the logic of deviation, stigma and exclusion (L. Horowitz, M. Leibovitz, R. Merton [11]) are gradually denying. In the scientific discourse, the drift of the marginal political is recorded: from the abnormal to the inversion and diffusion of the boundaries of the normative and the abnormal, to marginality as a new norm; from dysfunctional, destructive - to functional andconstructive; from a rare case, extremes - to marginality as a trend; from a temporary, transitional state - to totality and continuity of marginality; from the borderline state, when the subject, being outside, moves to the border of the systemic, non-marginal - to the diversification of the repertoire of marginal political practices.

At the level of social psychology and ideology, marginality is still identified as out-ofsystem, destructiveness, insecurity, and abnormality. In turn, researchers call into question the heuristic nature of the prescriptive, normative approach to marginality as a political phenomenon and actualize the descriptive approach, which presupposes a normativeneutral position.

The description of marginal political practices is mainly carried out at the intersection Political Studies and Urban Studies, Media Studies and Youth Studies (D. Bratich, R. Keyes, C. Montgomery [12], J. Nye [13], D. Citron, P. Snow, N. Postman, R. Chesney, S. Fuller [14], M. Holmes, O.A. Blinova [15], I.V. Vorobyova [16], Yu.A. Gorbunova, I.M. Dzyaloshinsky, A.N. Kravtsova, N.N. Koshkarova, O.V. Kruzhkova, Ya.N. Krupets, M.A. Molokova, O.V. Moroz, N.A. Nartova, N.V. Novikov, E.L. Omelchenko, R. Yu. Porozov, G.G. Pocheptsov, N.B. Ruzhentseva [17], O.F. Rusakova, I.A. Simonova [18], A.P. Chudinov [19], S.A. Shomova [20] and others). The digital space is positioned as the main practice stage. Owing to this fact, the marginality of the political practices of young people is revealed in their transboundary and hybrid nature. For example, flash mobs, Yandex rallies, media rides, petition practices, and political crowdsourcing reflect the emergence of the figital word, the permeability of the boundaries of the space of streets, avenues, squares and social media.The conjugation of the news agenda, political advertising, hype and entertainment gives rise to the practice of showization of politics, politainment. Post-irony as blurring the boundaries between serious and funny causes the mass character of political memes and media viruses among young people. The diffusion of facts appeals to emotions and personal faith, rational and irrational, truth and fiction forms the practice of fake news.

\section{Research methodology}

Currently, the study of political practices outlines a gradual shift from cataloging practices to trend-watching and foresight. Non-linearity is seen as a key characteristic of marginal political practices: practices of the type"black swan" spreading virulently; the strength of their influence on the future is underestimated, and the effects are poorly predictable and controllable.

As shown by the WVS [22] research, people's beliefs play a key role in economic development, the emergence and prosperity of democratic institutions, the growth of gender equality and the degree of effectiveness of public administration in society. As a result of Internet surfing through the channels, vlogs and accounts of public opinion leaders, young people get a more detailed picture of what is happening in the political sphere.And under the influence of the received ideas, they make a decision (directly or indirectly) to defend their interests in extra-institutional ways. In this regard, the study of the axiological 
foundations of the implementation of marginal political practices of young people for further forecasting of such practice type seems to be in great demand.

\section{Analysis of the value foundations of youth's marginal political practices}

Content analysis of social media accounts (VKontakte, Twitter, Facebook, Instagram), YouTube plots of public opinion leaders among young people, as well as news reports on political events and youth participation in them, made it possible to identify the following main value foundations of marginal political practices:

1. Patriotism treated as an orientation toward super-personal goals, the "common good", a willingness to influence the adoption of decisions that are significant for society and take responsibility for the country's future, which is incompatible with a passive attitude towards the political sphere. Patriotism as devotion, respect for people living in the country, pride in their achievements, admiration for the beauty of nature is opposed to loyalty to the state and has an oppositional, protest character.

According to the results of a survey by the Levada Center [23], despite a negative assessment of the functioning of the legal, economic and scientific spheres of Russian society in comparison with Western countries and the United States, Russian youth condemns their punitive policy towards Russia and its citizens, but at the same timebelieves that Russia's tough position to the Western world is justified.

In addition, the youth environment is characterized by a demand for local patriotism, the development of grassroots initiative practices. As M. Alekseevsky, a specialist in urban anthropology, notes: "almost every resident of a settlement registered on Vkontakte ... joins a group, for example, "Toropets is my love" ... And the number of these local groups in social networks and local forums that unite local residents, where some kind of life and discussion of urban problematic take place, is enormous.» [24]. An example of local patriotism is the support and expression of solidarity in the condemnation of the unfair detention of journalist Ivan Golunov during the Moscow protests in the summer of 2019. Through the expression of an active civic and political position, unity in the fight against injustice, a call to support someone who is in trouble, young people transmit their readiness to influence what is happening in the state and be responsible for its future, thus contributing to the formation of a new type of society.

2. Solidarity treated as indifference to problems going beyond the individualized life. This is the kind of solidarity that E. Durkheim called organic [21]. This solidarity is characterized by empathy and contributes to the formation of a "smart crowd" - a smart mob or, more commonly, a flash mob, capable of organizing to achieve a common goal. For example, the protests in Khabarovsk were accompanied by calls from residents of other cities to go out for walks, "feed the pigeons". Thus, a resident of Yekaterinburg was convicted of organizing an unauthorized rally, agitation and public speech against the current government after the publication of a video on TikTok in support of the protest in Khabarovsk.

The hashtag \#ЖывеБеларусь, posts and videos of opinion leaders (blogger and standup comedian Danila Poperechny, author of the Youtube-channel "Gentle Editor" Tatiana Mingalimova, actress Varvara Shmykova, rapper Mnogoznaal, blogger and journalist Yuri Dud') are widely spread as an expression of grief, anger, resentment, pain and fear reactions to events in the Republic of Belarus and, at the same time, - pride, support for Belarusians seeking for changes.

3. The value of nonviolence treated as the value orientation towards the peaceful resolution of political (or politicized) conflicts, an assessment of aggression and violence as completely unacceptable. 
The leader of the music group Litle Big Ilya Prusikin in an Instagram post opposes police violence in Belarus; the musician Oleg LSP calls these events "genocide of his own people", Yuri Dud', addressing the security forces, calls for stopping cruelty.

The Artist Anna Schemeleva-Konovalenko, born in Belarus, in Instagram posts demonstrates her work (white and red heart as a visualization of pain, on the one hand, and faith in the best, on the other) and declares her contempt for the aggressors; and also on her Instagram page announces participation in the exhibition "Flowers are better than bullets", organized in support of the artist and fem-activist Yulia Tsvetkova.

4. Justice treated as recognition of the equality of opportunities for every citizen, criticism of the monopolistic claims of the majority in the field of determining the norm, a proper way of life and recognition of the value of otherness, the coexistence of ideals. Thus, the journalist Karen Shainyan, within the framework of her own Youtube project and the singer Monetochka on the Instagram page, oppose homophobia and government initiatives aimed at stigmatizing and discriminating against representatives of the LGBT community.

Social-economic changes are also fueling youth's demand for justice and generating a range of digital political practices.For example, opposing the procedure for issuing passes, the lack of guarantees for wages' and jobs' preservation, complaining of financial difficulties under pandemic conditions and "self-isolation regime", residents of Russian cities participated in online rallies, leaving protest comments in the "Yandex. Maps" and Yandex.Navigator" ("Feed my cats, and I will stay at home!", "Or emergency, or pay loans and utility costs yourself!","You can't even run alone," etc.). Memes also become a reaction to the introduction of a new tax system against the backdrop of a crisis in the economy ("Russians are calculating how much they need to earn in order not to get under new taxes").

Fairness is also understood as honesty, which is expressed, for example, in the dissemination of demands for independent investigations on social networks, the change of government, and protests against falsification of election results.

So, on the website Change.org petitions demanding an independent investigation of the environmental disaster in Kamchatka are being created, and the hashtags \#Save Kamchatka are being distributed. The author of a non-political, but rather entertaining and educational show on Youtube, Tatyana Mingalimova, for the first time publishes a post on political topics in connection with the poisoning of Alexey Navalny, calling this event "The Heavy Middle Ages". Danila Poperechny in his video blog calls for a vote against amendments to the Constitution. Activist Zalina Marshenkulova, author of the YouTube channel "Injustice squared", calls the adopted amendments, in particular, the abolition of the primacy of international law, "an attempt to turn Russia into North Korea or Orthodox Iran".

5. Independence treated as striving for freedom from authorities, exercising the right to one's own choice, achieving economic and social success, as well as personal consistency. The political activity of young people is one of the ways to overcome all economic, political and other vicissitudes in order to become an independent subject, identical to itself.

Mistrust of the values broadcast by the pro-government media, the lack of effective platforms for interaction between young people and the authorities, draw the attention of young people to the content broadcast by young, mainly oppositional, politicians such as Nikolai Bondarenko, Lyubov Sobol, Ilya Yashin.The content of their Youtube channels encourages young people to express their position openly, especially if it is opposite to the official broadcast, and to abandon traditional values in favor of the values of a market economy and democracy. 


\section{Conclusion}

As a result of this study, we came to the conclusion that, in general, the value orientations of Russian youth that underlie marginal political practices (including protest ones) reflect a global shift from traditional values to secular-rational values, from the values of survival associated with ethnocentric worldview and a low level of trust and tolerance - to the values of self-expression that, in the context of digitalization, give priority to environmental protection, increasing tolerance, freedom of choice, equality of opportunity, as well as increasing requirements for citizen participation in economic and political decision-making [25].

The comprehension of the axiological foundations of young people political activities will make it possible to learn better the origins and goals of their marginal behavior, which will provide an opportunity to minimize the destructive consequences and increase the effectiveness of management, thus ensuring the stable development of the state in general or of a specific region in particular.

\section{Acknowledgment}

The research was carried out with the support of the Russian Foundation for Basic Research and ANO EISI, project No. 20-011-31736.

\section{References}

1. K. Crouch, Post democracy (2010)

2. J. Rancière, On the edge of political (2006)

3. J. Urri, Sociology Beyond Societies: A Vision of Mobility for the Central Agricultural Institute of the Century (2012)

4. A. Vafin, Azimuth of Scientific Research: Economics and Administration, 4, s. 307 (2017)

5. E. V. Golovatsky, Bulletin of Kemerovo State University, 1 (57), 73 (2014)

6. S.P. Gurin, Marginalized anthropology (2000)

7. L. L. Shpak, E. V. Golovatsky, Bulletin of Kemerovo State University, 2 (62), 105 (2015)

8. G. Simmel, Most i dver'. Sociology of power (2017)

9. R.E. Park, Cultural Conflict and The Marginal Man, 2, 172 (1998)

10. E.V. Stonequist, Marginalized Man: A Study of Personality and the Cooler Conflict (2006)

11. R. Merton, Social theory and social structure (2006)

12. K. Montgomery, Generation Digital: Politics, Commerce, and Childhood in the Age of the Internet (2009)

13. J. Naj, Free Thought-XXI, 10 (2004)

14. S. Fuller, Science (Concepts in Social Sciences) (1997)

15. O. Blinova, Yu. Gorbunova, R. Porozov, A. Obolenskaya, Advances in Social Science, Education and Humanities Research, 331, 91 (2019)

16. O.V. Kruzhkova, I.V. Vorobyeva, Moscow university psychology bulletin, 4, 160 (2019) 
17. N.B. Ruzhentseva, Political linguistics, 4, 46 (2015)

18. I.V. Vorobyeva, O.V. Kruzhkova, I.A. Simonova, Pedagogical Education in Russia, 5, $45(2015)$

19. S.A. Shomova, Biznes. Obshhestvo. Vlast’, 22, 28 (2015)

20. A.P.Chudinov, Political linguistics, 2, 53 (2012)

21. E. Durkheim, O razdelenii obshhestvennogo truda (1996)

22. WVS, http://www.worldvaluessurvey.org

23. The Levada Center, https://www.levada.ru

24. PostNauka, https://postnauka.ru

25. World Values Survey, http://www.worldvaluessurvey.org 